\title{
ANALISIS NONLINEAR DINDING GESER BETON BERTULANG MENGGUNAKAN METODE ELEMEN HINGGA
}

\author{
Fatkurotif \\ Sri Murni Dewi \\ Achfas Zacoeb
}

\begin{abstract}
Abstrak: Tujuan penelitian ini untuk mengetahui pola beban perpindahan dan keretakan nonlinear dinding geser beton bertulang menggunakan metode elemen hingga smeared element. Kajian ini menggunakan model elemen isoparametrik 8 titik nodal dengan jumlah 90 elemen. Hasil kajian dibandingkan dengan hasil eksperimental penelitian sebelumnya. Terdapat dua model dinding geser yang digunakan yaitu SW-3 dengan persentase tulangan 0,28\% dan model SW-50 dengan persentase tulangan $1,24 \%$. Hasil kajian menunjukkan bahwa model SW-3 memiliki kurva beban perpindahan hasil analisis numerik cukup berhimpit dengan hasil eksperimental, akan tetapi pola retak analisis numerik terjadi perambatan retak, sedang hasil uji eksperimental tidak terjadi perambatan retak melainkan gap opening pada dinding geser. Model SW50 dengan tulangan normal menunjukkan selain kurva beban perpindahan memiliki kesamaan juga perambatan retak mendekati hasil eksperimental.
\end{abstract}

Kata-kata Kunci: dinding geser, nonlinear, elemen hingga

\begin{abstract}
Nonlinear Analysis of Reinforced Concrete Shear Wall Using Finite Element Method. The aim of this research is to know the displacement load pattern and the nonlinear crack of reinforced concrete shear wall using finite element of smeared element. This study uses an 8-point nodal isoparametric element model with a total of 90 elements. The results of the study are compared to the results of previous experimental studies. There are two models of shear wall used, SW-3 with the percentage of reinforcement 0,28\% and SW-50 model with the percentage of reinforcement 1,24\%. The result of the study shows that SW-3 model has a load displacement curve of numerical analysis results almost similar to the experimental results and the pattern of crack numerical analysis show an occurance of crack propagation, on the other hand the experimental results do not show an occurance of crack propagation, onlu gap opening on the shear wall. The SW-50 model with normal reinforcement shows that in addition to the similarity of the displacement load curve, the crack propagation is also almost similar to the experimental results.
\end{abstract}

Keywords: shear wall, nonlinear, finite element

$\mathrm{P}$ erilaku beton yang nonlinear elastis merupakan permasalahan tersendiri dalam pemodelan dengan metode elemen

hingga. Nonlinieritas material pada struktur beton sangat dipengaruhi oleh munculnya retak karena setelah retak perilaku

Fatkurotif adalah mahasiswa Pascasarjana Jurusan Teknik Sipil Universitas Brawijaya. Email: fat291177@gmail.com. Sri Murni dan Achfas Zacoeb adalah Dosen Jurusan Teknik Sipil Universitas Brawijaya. Alamat Kampus: Jl. M.T. Haryono No. 167 Malang 65145. 
elemen beton berubah dari isotropik menjadi ortotropik, padahal pada tahap beton mengalami retak pertama baja tulangan masih dalam kondisi elastis. Pengaruh beban aksial juga akan mempengaruhi perilaku nonlinearitas struktur, pada struktur yang hanya menerima beban bending akan lebih cepat mengalami retak jika dibandingkan dengan struktur yang menerima beban bending dan beban aksial tekan. Perilaku tersebut memerlukan cara khusus dalam mengevaluasi kekakuan elemen karena meskipun dalam kondisi elastis kekakuan material beton kenyataannya tidak menunjukkan sifat linier. Oleh karena itu pada setiap inkrementasi beban kekakuan material selalu diperbaiki. pada penelitian ini akan dikembangkan suatu model finite element yang dapat merepresentasikan perilaku dinding geser beton bertulang dengan memasukkan sifat nonlinieritas material sehingga dapat mensimulasikan pola serta propagasi retak pada setiap inkrementasi beban lateral.

Dinding geser merupakan suatu subsistem gedung yang memiliki fungsi utama untuk menahan gaya lateral akibat beban gempa. Keruntuhan pada dinding geser disebabkan oleh momen lentur karena terjadinya sendi plastis pada kaki dinding. Semakin tinggi suatu gedung, simpangan horizontal yang terjadi akibat gaya lateral akan semakin besar, untuk itu sering digunakan dinding geser pada struktur bangunan tinggi untuk memperkaku struktur sehingga simpangan yang terjadi dapat berkurang. Dinding geser juga berfungsi untuk mereduksi momen yang diterima struktur rangka sehingga dimensi struktur rangka dapat dibuat seefisien mungkin pada struktur bangunan tinggi akibat gaya lateral. Gaya lateral yang terjadi pada suatu gedung, baik diakibatkan oleh beban gempa maupun angin akan disebar melalui struktur lantai yang berfungsi sebagai diafragma horizontal yang kemudian akan ditahan oleh dinding geser karena memiliki kekakuan yang besar untuk menahan gaya lateral.

Model elemen smeared element pertama kali diusulkan oleh Rashid seperti dikutip oleh Subranto (2007), pada model ini baja tulangan dianggap terdistribusi merata dengan element beton, retak yang terbentuk pada element juga dianggap merata pada elemen. beton dalam kondisi elastis penuh dianggap sebagai material isotropik sedangkan setelah retak dianggap sebagai material ortotropik

Ibrahim dan Suter (1994) melakukan pemodelan struktur dinding geser beton bertulang menggunakan metode Elemen terdistribusi merata. secara prinsip sama dengan yang diungkapkan oleh Veccio (1988, 1989) akan tetapi pada matrik konstitutif beton terdapat perbedaan, pada kondisi orthotropik tetap memasukkan unsur poisson rasio tanpa faktor retensi geser $(\beta)$ pada modulus gesernya. Akibat pengaruh beban aksial yang secara otomatis akan meningkatkan kekuatan geser penampang yang dalam hal ini kapasitas aksial yang bekerja dibatasi maksimum beban aksial kondisi setimbang (balance). Pembahasan mengenai matrik kekakuan isotropik dan ortotropik akan dibahas pada bab selanjutnya.

Pada daerah tarik dan tekan, sebelum retak atau hancur tekan, beton dianggap sebagai material isotropik dengan matrik kekakuan isotropik tarik persamaan 1:

$$
D_{m}^{\prime}=\frac{E}{\left(1-v^{2}\right)}\left[\begin{array}{ccc}
1 & v & 0 \\
v & 1 & 0 \\
0 & 0 & \frac{1-v}{2}
\end{array}\right]
$$

Setelah beton yang mengalami retak akan didahului oleh terjadinya tegangan tarik yang melampaui tegangan tarik beton. Kegagalan material akan menyebabkan degradasi kekakuan geser dan kekakuan normal. Jika tegangan tarik lebih besar dari tegangan tarik beton, hubungan tegangan dan regangan material berubah menjadi persamaan 2 . 


$$
D_{m}^{\prime}=\frac{E}{\left(1-v^{2}\right)}\left[\begin{array}{ccc}
\eta_{n} & v \eta_{n} & 0 \\
v \eta_{n} & 1 & 0 \\
0 & 0 & \eta_{s} \frac{1-v}{2}
\end{array}\right] \ldots \ldots . . .(2)
$$

pada daerah tekan di mana tegangan tekan terjadi cukup besar akibat beban lateral dan beban aksial maka jika beton mengalami hancur tekan (chrused) maka terjadi perubahan dari matrik isothropik tekan ke matrik orthotropik tekan, matrik orthotrpik tekan seperti persamaan 3 .

$$
D_{m}^{\prime}=\frac{1}{\left(1-v^{2}\right)}\left[\begin{array}{ccc}
E_{1} & v E_{12} & 0 \\
v E_{12} & E_{2} & 0 \\
0 & 0 & \frac{1-v}{2} E_{12}
\end{array}\right] \ldots \text { (3) }
$$

dengan:

$E_{1}=$ Modulus tarik beton,

$E_{2}=$ modulus tekan beton .

$$
\boldsymbol{\eta}_{\mathbf{r}}=0.001, \boldsymbol{\eta}=0.5
$$

Secara umum material baja mempunyai karakteristik yang sama atau dapat dikatagorikan pada material homogen isotropik, dimana partikel pembentuk ke seluruh ke arah merupakan satu jenis partikel. Hal ini yang membuat karakteristik baja menjadi lebih sederhana dibandingkan material beton. Model elemen terdistribusi merata menganggap bahwa tulangan terdistribusi secara merata pada elemen beton dengan arah tertentu. $\mathrm{Hu}-$ bungan tegangan-regangan dimasukkan ke dalam konstitutif material beton, sehingga pada model ini konstitutif yang digunakan adalah kekakuan komposit antara beton dan tulangan. Model ini juga menganggap bahwa interaksi antara tulangan dan beton lekat sempurna yang artinya dalam perhitungan diasumsikan tidak terjadi bond slip.

Vecchio $(1988,1989)$ yang memodelkan tulangan longitudinal dan transversal sebagai model terdistribusi merata untuk menganalisis perilaku membrane beton bertulang. Hubungan konstitutif tu- langan dinyatakan dalam persamaan 4 , yang kemudian ditambahkan secara langsung dengan matrik kekakuan material beton.

$$
D_{s}^{\prime}=\left[\begin{array}{ccc}
\rho_{n} E_{n} & 0 & 0 \\
0 & \rho_{s} E_{s} & 0 \\
0 & 0 & 0
\end{array}\right] \ldots \ldots \ldots \ldots \ldots
$$

dengan $D$ 's adalah matrik konstitutiv material, $\rho_{n}$ dan $\rho_{s}$ masing - masing adalah rasio tulangan arah sumbu memanjang dan melintang tulangan, sedangkan $E_{n}$ dan $E_{s}$ adalah modulus sekan baja tulangan. Penggabungan antara matrik kekakuan beton dan matrik kekakuan tulangan pada kondisi beton isotropik seperti pada persamaan 5 .

$$
\left\{\begin{array}{l}
\sigma_{x} \\
\sigma_{y} \\
\tau_{x y}
\end{array}\right\}=\left[\frac{E_{c}}{1-v^{2}}\left[\begin{array}{ccc}
1 & v & 0 \\
v & 1 & 0 \\
0 & 0 & \frac{1-v}{2}
\end{array}\right]+\left[\begin{array}{ccc}
\rho_{n} E_{n} & 0 & 0 \\
0 & \rho_{s} E_{s} & 0 \\
0 & 0 & 0
\end{array}\right]\left\{\begin{array}{l}
\varepsilon_{x} \\
\varepsilon_{y} \\
\lambda_{x y}
\end{array}\right\}(5)\right.
$$

Matrik kekakuan elemen beton dan tulangan di mana beton sudah mengalami retak akan tetapi baja tulangan masih elastis, menjadi persamaan 6 .

$$
\left\{\begin{array}{l}
\sigma_{x} \\
\sigma_{y} \\
\tau_{x y}
\end{array}\right\}=\left[\frac{E_{c}}{1-v^{2}}\left[\begin{array}{ccc}
\eta_{n} & v \eta_{n} & 0 \\
v \eta_{n} & \eta_{n} & 0 \\
0 & 0 & \eta_{s} \frac{1-v}{2}
\end{array}\right]+\left[\begin{array}{ccc}
\rho_{n} E_{n} & 0 & 0 \\
0 & \rho_{s} E_{s} & 0 \\
0 & 0 & 0
\end{array}\right]\right]\left\{\begin{array}{c}
\varepsilon_{x} \\
\varepsilon_{y} \\
\lambda_{x y}
\end{array}\right\}(6)
$$

Dengan nilai dan mempunyai nilai poisson rasio tetap. Sedangkan untuk matrik kekakuan elemen beton dan tulangan dimana beton sudah mengalami hancur tekan, persamaan 7 .

$\left\{\begin{array}{l}\sigma_{x} \\ \sigma_{y} \\ \tau_{x y}\end{array}\right\}=\left[\frac{1}{\left(1-v^{2}\right)}\left[\begin{array}{ccc}E_{1} & v E_{12} & 0 \\ v E_{12} & E_{2} & 0 \\ 0 & 0 & \frac{1-v}{2} E_{12}\end{array}\right]+\left[\begin{array}{ccc}\rho_{n} E_{n} & 0 & 0 \\ 0 & \rho_{s} E_{s} & 0 \\ 0 & 0 & 0\end{array}\right]\right]\left\{\begin{array}{l}\varepsilon_{x} \\ \varepsilon_{y} \\ \lambda_{x y}\end{array}\right\}(7)$

Dengan nilai poisson rasio tetap, $E_{l}$ dan $E_{2}$ merupakan modulus secan tarik dan tekan,

$$
E_{12}=\sqrt{E_{1} E_{2}}
$$


Struktur dinding geser pada tesis ini dihitung menggunakan metode elemen hingga di mana untuk struktur dinding geser dengan ketebalan konstan dan terbatas sehingga model plane stress lebih tepat dipakai dalam pemodelan ini, pada model plane stress tegangan yang terjadi pada arah tegak lurus bidang dianggap nol.

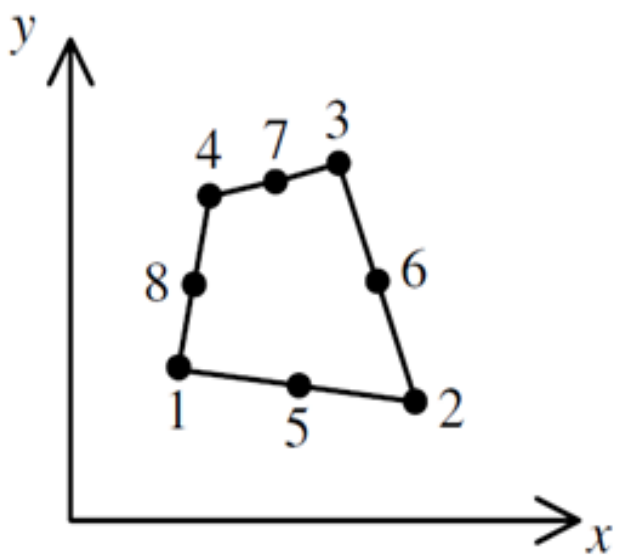

\section{Gambar 1. Elemen Kuadratik} Kuadrilateral

(Sumber: Kattan, 2008)

Matrik hubungan konstitutif tegangan-regangan $[D]$ ada beberapa bentuk tergantung pada kondisi tegangan material yang dianalisis, kondisi material isotropik dan kondisi orthotropik dijelaskan pada persamaan 1 sampai dengan 7 , sedangkan martrik kekakuan elemen kuadratik kuadrilateral 8 titik nodal persamaan 8 .

$$
[k]=t \int_{-1}^{1} \int_{-1}^{1}[B]^{T}[D][B][J] d \xi d \eta
$$

Di mana $\mathrm{t}$ adalah ketebalan elemen, $[\mathrm{J}]$ adalah matrik Jacoby. Elemen quadrilateral 8 titik nodal memiliki ukuran 16 degrees of freedom dengan 2 degree of freedom pada masing-masing titik nodalnya. Matrik kekakuan global [K] memiliki ukuran matrik $2 \mathrm{n} \times 2 \mathrm{n}$ di mana $\mathrm{n}$ adalah jumlah titik nodal, jika matrik kekakuan global sudah didapatkan maka akan didapatkan persamaan 9 .

$[\mathrm{K}]\{\mathrm{U}\}=\{\mathrm{F}\}$
Di mana $U$ adalah vektor perpindahan global dan $\mathrm{F}$ adalah vektor gaya, untuk mendapatkan vektor tegangan digunakan persamaan 10 .

$\{\sigma\}=[\mathrm{D}][\mathrm{B}]\{\mathrm{u}\}$

Elemen Kadratik Kuadrilateral dapat dilihat pada Gambar 1. Adapun maksud dan tujuan dari penelitian ini adalah: (1) mengetahui perilaku non-linear dinding geser beton bertulang menggunakan metode elemen hingga smeared element (elemen terdistribusi merata), (2) mendapatkan gambaran mengenai pola retak dan perambatan retak dinding geser beton bertulang menggunakan metode elemen hingga smeared element (elemen terdistribusi merata), dan (3) mengetahui tingkat akurasi metode elemen hingga smeared element (elemen terdistribusi merata) jika dibandingkan dengan hasil eksperimental pada dinding geser beton bertulang.

\section{METODE}

Studi numerik pada penelitian ini digunakan untuk memperediksi perilaku dinding geser dalam hal beban perpindahan dan perambatan retak. Validasi perhitungan sangat perlu dilakukan untuk mengetahui tingkat akurasi perhitungan apakah sudah mendekati hasil eksperimental atau tidak. Dalam tesis ini digunakan data hasil experimental struktur dinding geser beton bertulang yang dilakukan oleh Surya dan Wibowo (2017) dan Silalahi, dkk. (2016) yang berupa kurva beban-perpindahan dan pola keretakan struktur. Pada pengujian tersebut peneliti melakukan pengujian beberapa specimen dinding geser beton bertulang dengan beberapa variasi dimensi antara lain: (1) Spesimen SW-3: dinding geser dengan ukuran 900 x $450 \mathrm{~mm}$, tebal $100 \mathrm{~mm}$ dapat dilihat pada Gambar 2. Jarak antar tulangan longitudinal Ø6-392, sedangkan jarak antar tulangan transversal Ø6-225. Beban aksial konstan $\mathrm{P}=14,69 \mathrm{kN}$, Mutu 


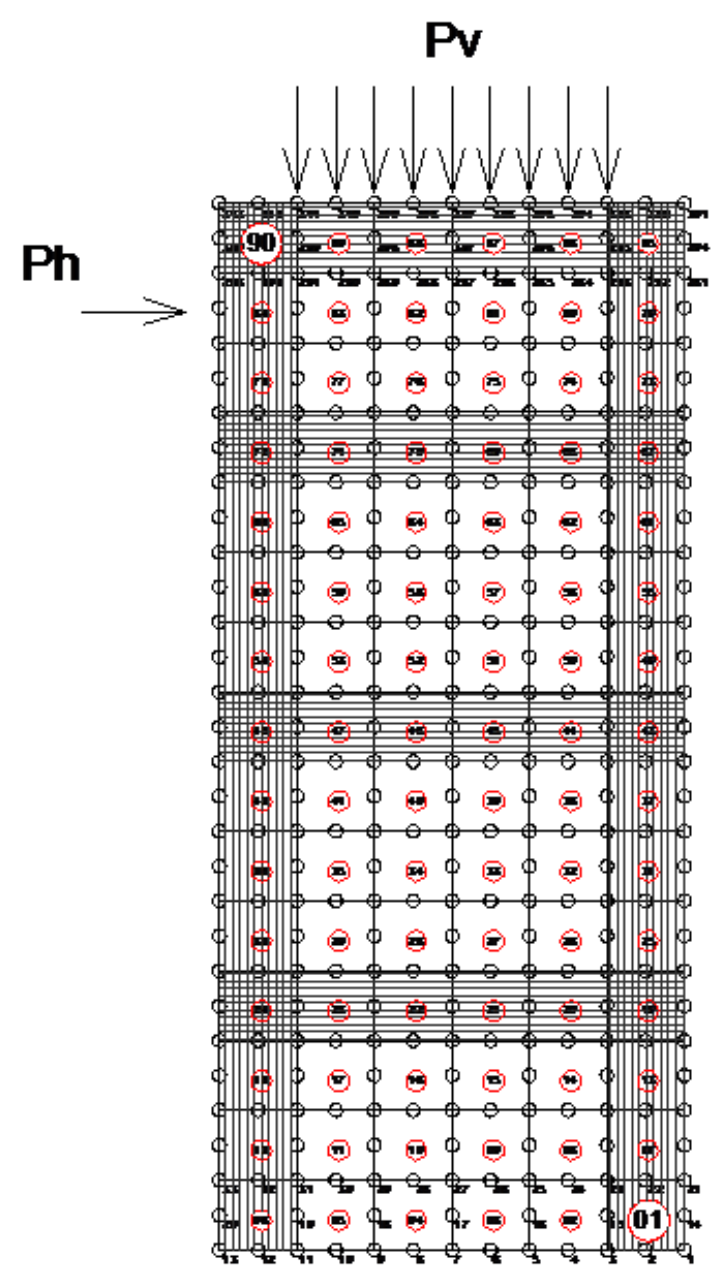

Keterangan :

Elemen dengan tulangan smeared lertur

Eemen dengan tulangan smeared geser

Eemen dengan tulangan smeared lentur dan geser

Eemen tanpa tulangan smeared

\section{Gambar 2. Diskritisasi Elemen Dinding Geser Beton Bertulang Spesimen SW-3}

beton $18 \mathrm{MPa}$, tegangan leleh fy $=280$ $\mathrm{MPa}$ dan modulus elastisitas baja tulangan vertikal maupun horizontal $E_{s}=$ 150.000 MPa. Aspek rasio dinding geser $\mathrm{a}=1,78>1$, perilaku lentur, rasio tulangan $=0,28 \%$ (tulangan ringan); (2) Specimen SW-50: dinding geser dengan ukuran 800 x $400 \mathrm{~mm}$, tebal $80 \mathrm{~mm}$, jarak tulangan longitudinal Ø8-50, sedangkan jarak antar tulangan transversal $\varnothing 8-150$ dapat dilihat pada Gambar 3. Beban aksial konstan $\mathrm{P}=30$

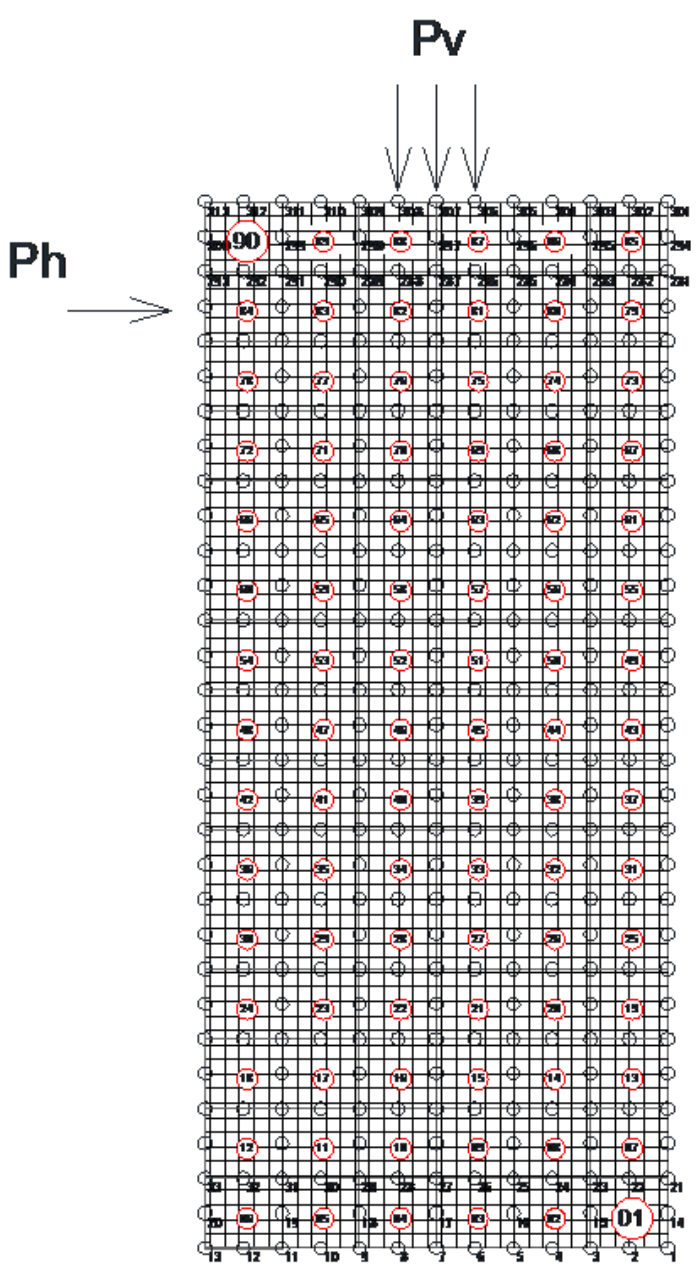

Keterangan :

Elemen dengan tulangan smeared lentur

Elemen dengan tulangan smeared geser

Gambar 3. Diskritisasi Elemen Dinding

Geser Beton Bertulang

Spesimen SW-50

$\mathrm{kN}$, tegangan tekan beton $20 \mathrm{MPa}$, tegangan leleh baja tulangan vertikal dan horizontal fy $=378,86 \mathrm{MPa}$, modulus elastis baja $E_{s}=210.000 \mathrm{mpa}$. Aspek rasio dinding geser $\mathrm{a}=2$, perilaku lentur, rasio tulangan $\mathrm{r}=2,52 \%>1,0 \%$ (tulangan normal ).

Alogaritma program untuk analisis dinding geser beton bertulang dilakukan dengan melakukan analisis pembebanan bertahap untuk mendapatkan respons non-linear dinding geser beton bertulang. Diagram alir analisis nonlinear metode elemen smeared element dapat dilihat pada Gambar 4. 


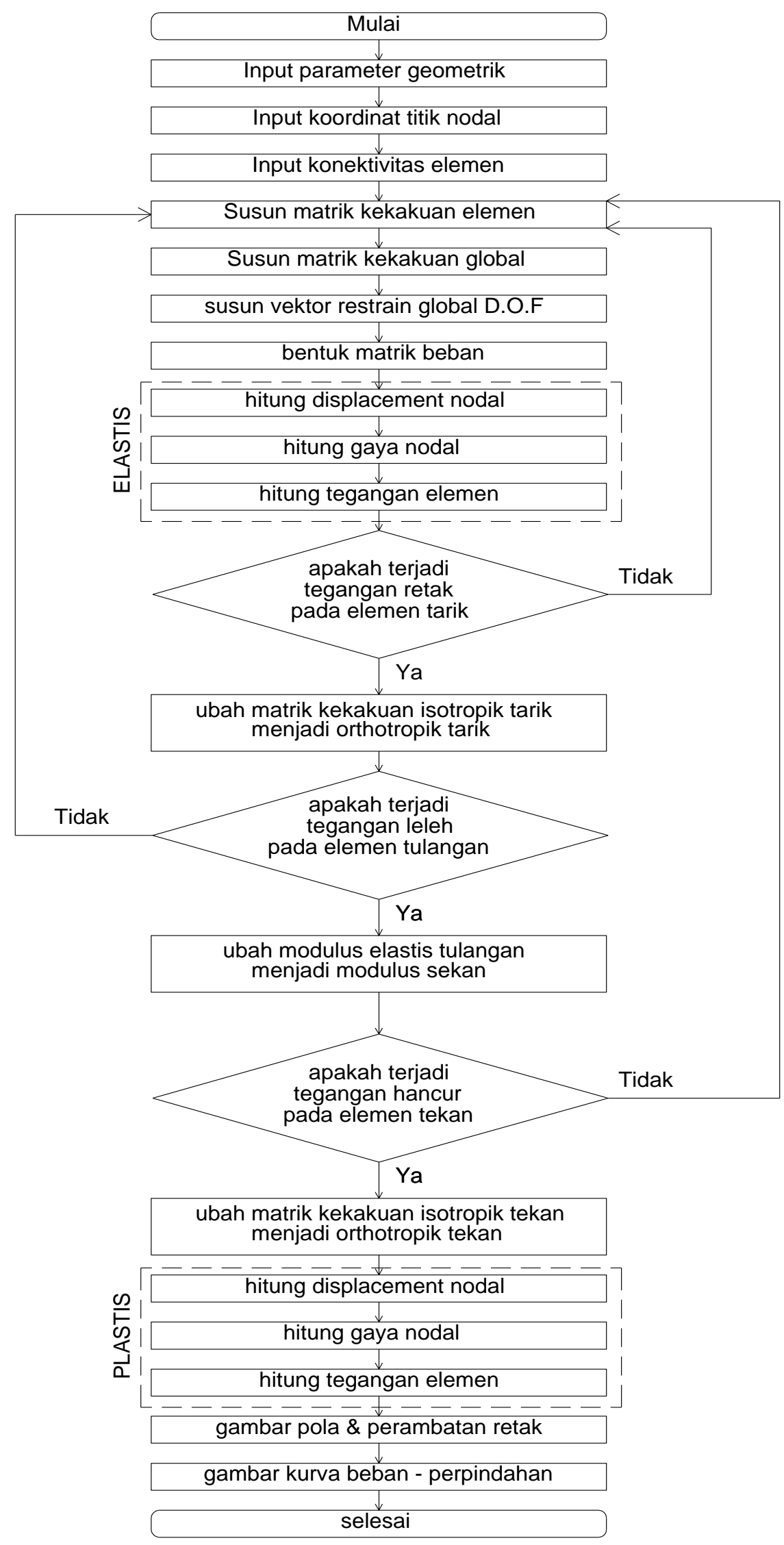

Gambar 4. Diagram Alir Analisis Nonlinear Metode Elemen Smeared Element 
Pada setiap tahapan pembebanan akan di lihat elemen mana yang telah mengalami retak akibat beban tarik (tension region), jika ada elemen yang mengalami retak yang berarti tegangan titik gauss point melebihi tegangan tarik beton maka matrik kekakuan harus dirubah dari isotropik menjadi ortotropik, juga pada kondisi area tekan (tension region) jika pada tahapan pembebanan terjadi tegangan hancur dimana tegangan tekan pada pusat elemen lebih besar dari tegangan hancur beton $\left(f_{c u}\right)$ maka matrik kekakuan elemen isotropik harus dirubah ke matrik kekakuan ortotropik dan dilanjutkan dengan inkrementasi beban selanjutnya.

\section{HASIL}

\section{Dinding Geser SW-3}

Hasil analisis numeric beban perpindahan pada dinding geser Spesimen SW3 ditunjukkan dengan kurva melengkung dimulai dari pusat koordinat menuju angka maksimum di atas 1500 , seperti terlihat pada Gambar 5 .
Hasil analisis numerik Pola Retak pada dinding geser Spesimen SW3 ditunjukkan dengan garis-garis mendatar yang makin kebawah makin banyak, seperti terlihat pada Gambar 6b. Makin kebawah terjadi keretakan makin besar. Hasil $\mathrm{Nu}$ merik dan Eksperimen pada Pola Retak Spesimen SW3 lihat pada Gambar 6.

\section{Dinding Geser SW-50}

Hasil analisis numeric beban lateraldrift (\%) Spesimen SW-50 ditunjukkan dengan kurva melengkung dimulai dari pusat koordinat menuju angka minimum di mendekati -7.000 , seperti terlihat pada Gambar 7.

Hasil analisis numerik Pola Retak pada dinding geser Spesimen SW-50 ditunjukkan dengan garis-garis mendatar yang makin kebawah makin banyak, seperti terlihat pada Gambar 8b. Makin kebawah terjadi keretakan makin besar dan retak lebih banyak daripada specimen SW3. Gambar 8 hasil numerik dan eksperimen pola retak spesimen SW-50.

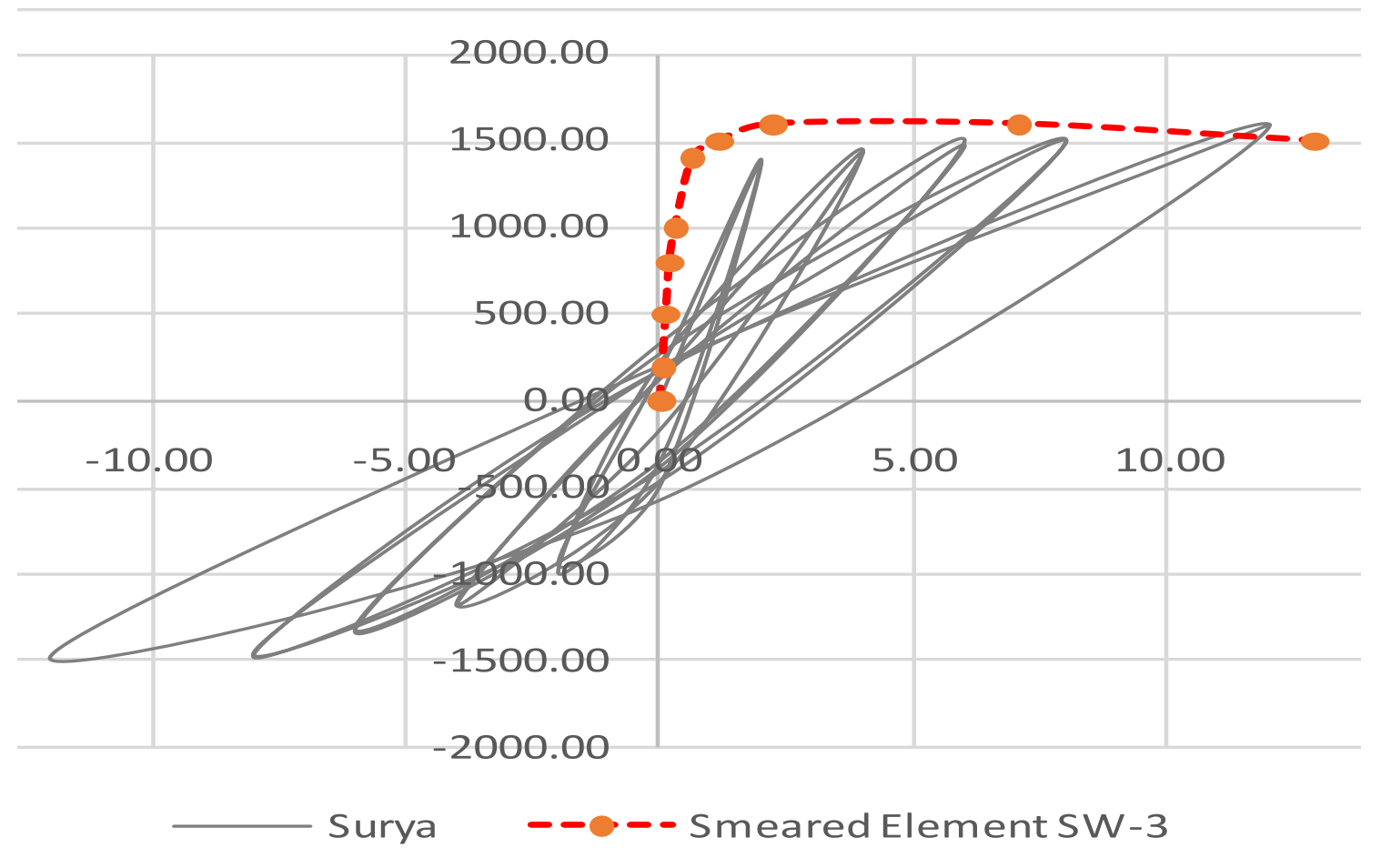

Gambar 5. Hasil Numerik dan Eksperimen Beban Perpindahan Spesimen SW3 


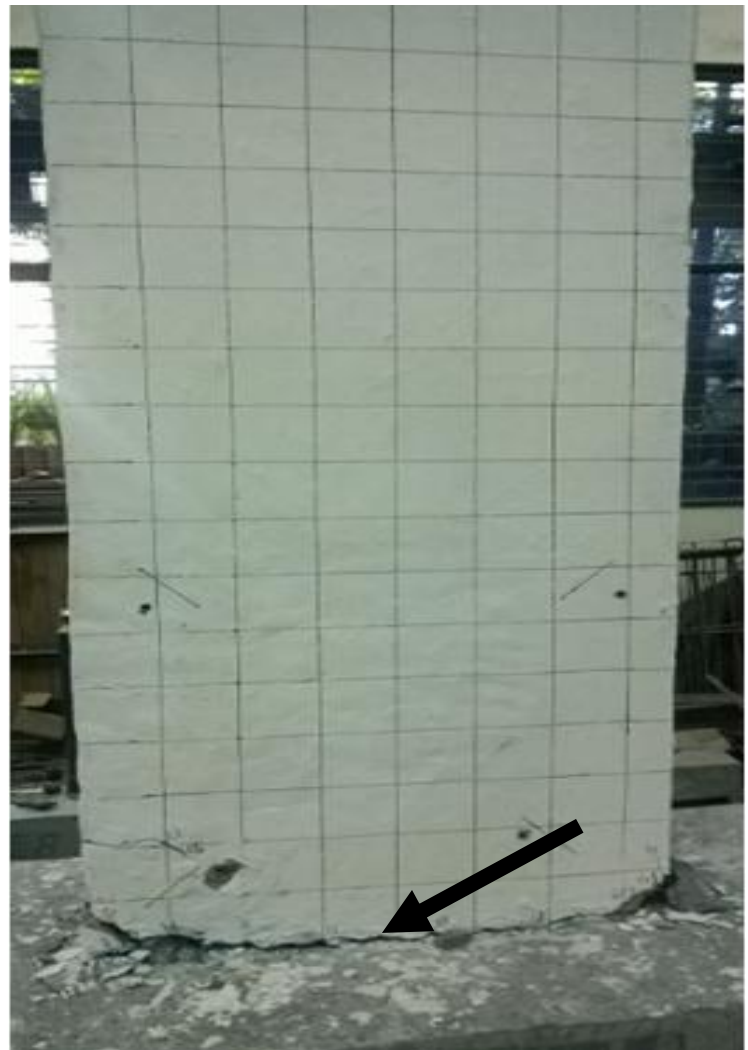

Pola retak hasil uji eksperimental

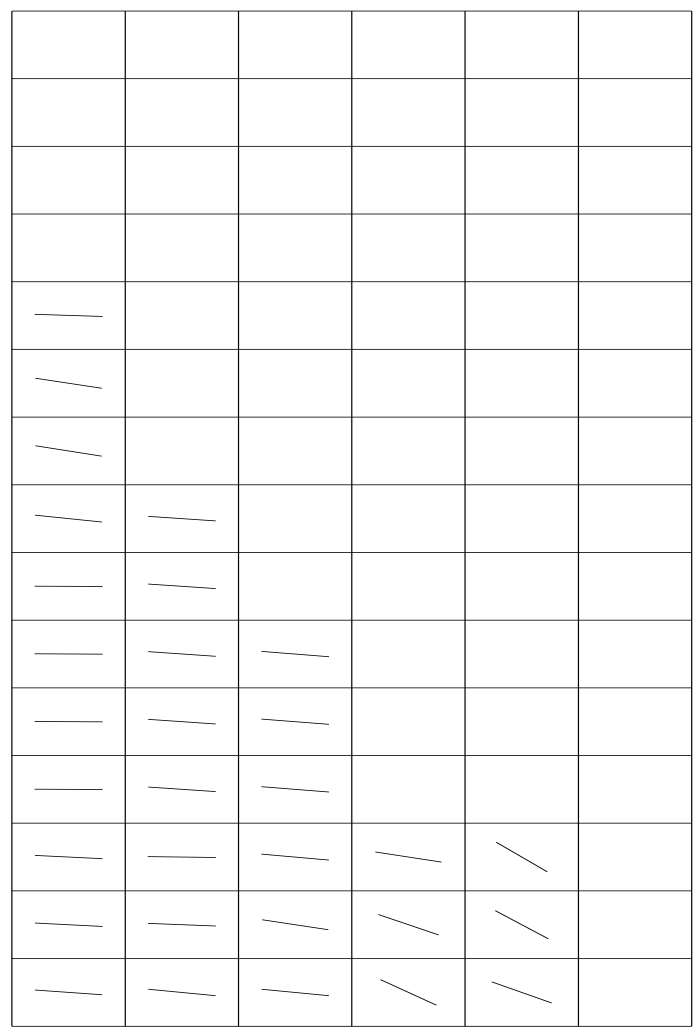

Pola retak hasil analisis numerik

Gambar 6. Hasil Numerik dan Eksperimen pada Pola Retak Spesimen SW3

(Sumber: Surya dan Wibowo, 2017)

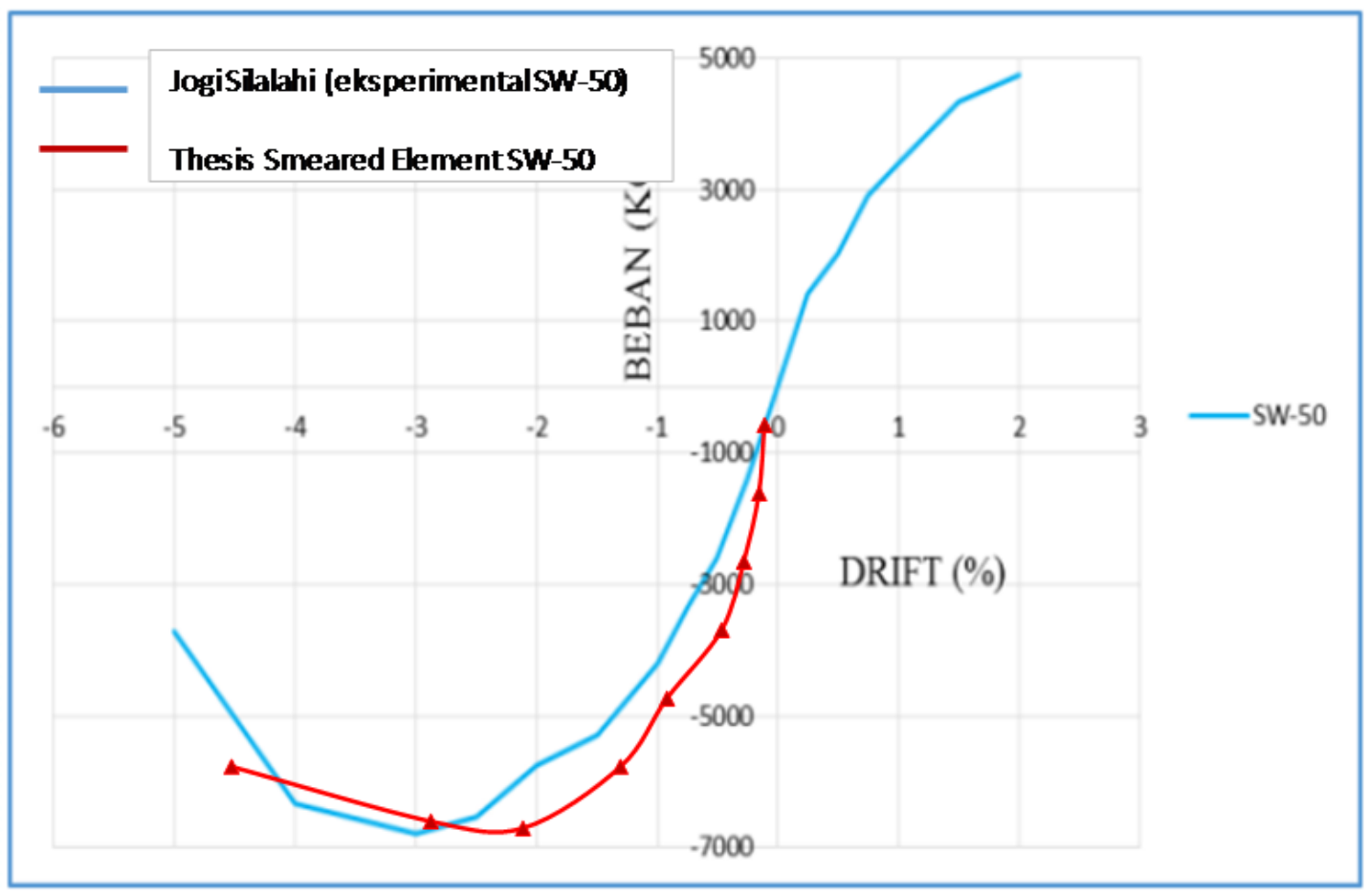

Gambar 7. Hasil Numerik dan Eksperimen pada Beban Lateral-Drift Spesimen SW-50 


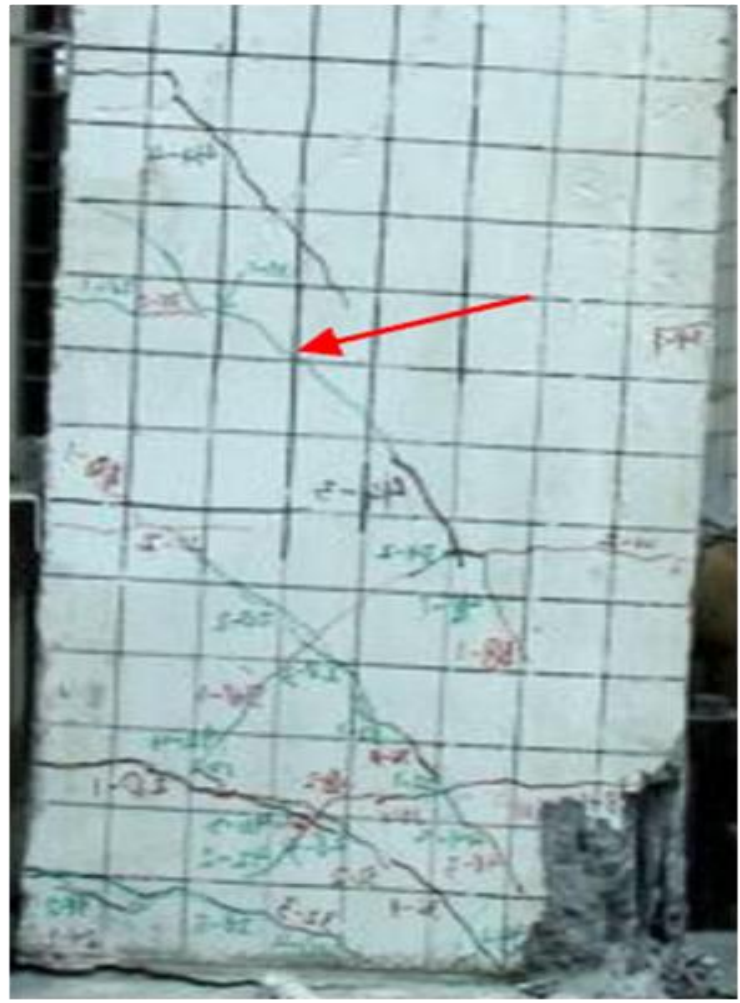

Pola retak hasil uji eksperimental

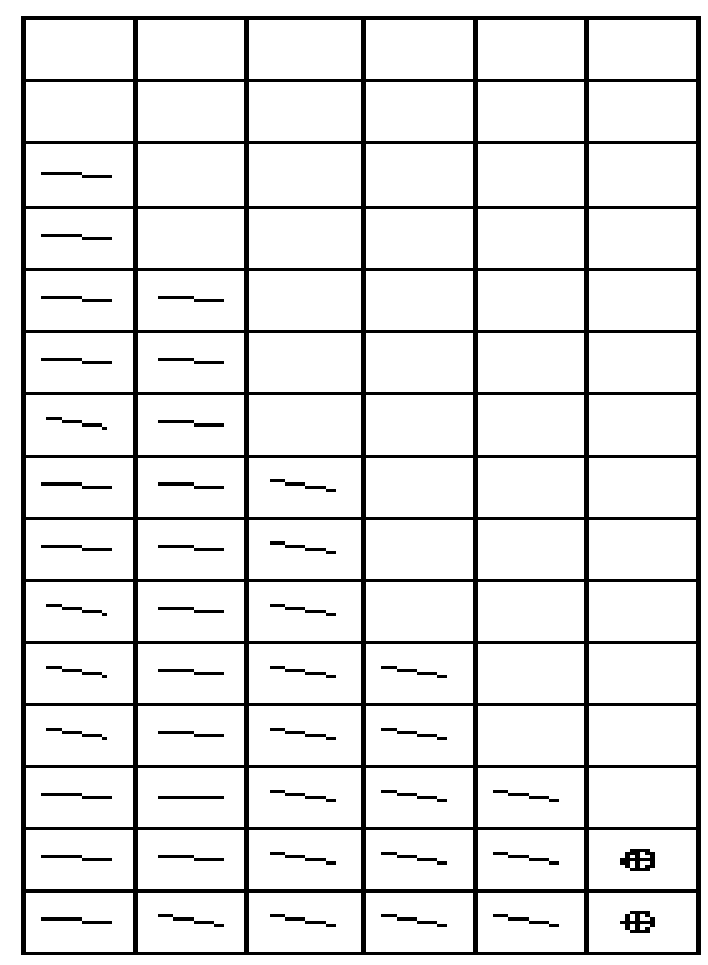

Pola retak hasil analisis numeric

\section{Gambar 8. Hasil Numerik dan Eksperimen Pola Retak Spesimen SW-50}

(Sumber: Silalahi, dkk. 2016)

\section{PEMBAHASAN}

\section{Dinding geser SW-3}

Komparasi dengan hasil eksperimental yang dilakukan oleh peneliti sebelumnya dialkukan untuk mengetahui tingkat akurasi baik dalam hal perilaku beban perpindahan maupun perambatan retaknya seperti pada spesimen dinding geser SW-3. beban aksial konstan sebesar $\mathrm{P}=$ $22,56 \mathrm{kN}$. Beban lateral bertahap yang dikenakan yaitu beban monotonik dengan tahapan seperti pada Tabel 1 .

Hasil perhitungan numerik berupa kurva beban perpindahan dibandingkan dengan hasil eksperimen yang berupa diagram hiteresis hasilnya cukup berhimpit hal ini menunjukkan bahwa metode elemen hingga elemen terbagi merata mampu memberikan solusi yang mendekati uji eksperimental untuk respons nonlinear struktur dinding geser seperti Gambar 5 namun terdapat perbedaan dalam
Tabel 1. Beban Inkrementasi SW-2

\begin{tabular}{lcc}
\hline No. & $\begin{array}{c}\text { Penambahan } \\
\text { Beban }(\mathbf{k N})\end{array}$ & $\begin{array}{c}\text { Kumulatif } \\
(\mathbf{k N})\end{array}$ \\
\hline 1. & 7 & 7 \\
2. & 5 & 12 \\
3. & 6 & 18 \\
4. & 2 & 20 \\
5. & 5 & 25 \\
6. & 5 & 30 \\
7. & 5 & 35 \\
8. & 5 & 40 \\
9. & -2 & 38 \\
10. & -3 & 35 \\
\hline
\end{tabular}

hal perambatan retak struktur. Pada Gambar 6a terlihat kondisi akhir benda uji hasil eksperimen menunjukkan tidak terjadi perambatan retak akan tetapi terjadi keretakan yang terus melebar di titik dasar dinding geser (yield penetration). Lemahnya ikatan antara dinding geser dengan pondasinya juga diakibatkan oleh minimnya tulangan vertikal dinding geser yang berperan besar terhadap gagalnya respons 
terhadap perambatan retak. penurunan kekakuan dan respon non-linier dinding geser dengan tulangan ringan dikarenakan oleh semakin melebarnya retak pada dasar dinding geser dan semakin besarnya pengaruh bond slip serta leleh pada tulangan yang terpusat di dasar dinding geser. Berbeda dengan konsep numerik dengan pendekatan metode elemen terbagi merata yaitu bahwa respons non-linier terjadi di akibatkan oleh retak yang merambat pada tiap penambahan beban lateral, tiap penambahan retak berarti kekakuan semakin menurun dan respons non-linier terjadi.

\section{Dinding geser SW-50}

Hasil kajian numerik spesimen dinding geser SW-50 menunjukkan respons yang mendekati hasil uji eksperimental baik dari segi kurva beban drift Gambar 7, maupun maupun dalam hal perambatan retaknya Gambar 8. Dari dua kondisi dinding geser tersebut dapat di katakan bahwa metode elemen hingga dengan pendekatan elemen terbagi lebih akurat untuk struktur dengan tulangan normal, untuk tulangan ringan belum bisa dilakukan kajian secara menyeluruh dikarenakan keterbatasan parameter yang digunakan dalam analisis numerik.

\section{SIMPULAN DAN SARAN}

Dari kajian numerik dan dibandingkan dengan kajian eksperimental dapat disimpulkan. Pertama, pada dinding geser dengan tulangan ringan respons beban perpindahan hampir mendekati uji eksperimental akan tetapi pada perambatan retaknya sangat berbeda karena dalam kajian numerik dengan metode elemen terbagi merata penurunan kekakuan struktur terjadi akibat perambatan retak seiring dengan pertambahan beban lateral. Kedua, respons dinding geser dengan tulangan normal baik dari hasil pengujian maupun dari kajian numerik menunjukkan respons yang hampir mendekati da- lam hal perambatan retak maupun beban perpindahan.

Berdasarkan kesimpulan disarankan bahwa analisis nonlinear dinding geser beton bertulang menggunakan metode elemen hingga dapat dilakukan terutama pada tulangan normal.

\section{DAFTAR RUJUKAN}

Ibrahim, K.S. \& Suter, G.T. 1994. Smeared Crack Models for Reinforced Concrete Masonry Shear Wall Analysis. Canada.

Kattan, P. 2008. Matlab Guide to Finite Element An Interactive Approach, Scond Edition, Springer-Verlag Berlin Heidelberg.

Subranto, S. 2007. Analisis Struktur Beton Bertulang dengan Pendekatan Smeared Crack dan Smeared Element Menggunakan Metode Elemen Hingga. Tesis tidak diterbitkan, Jurusan Teknik Sipil, Undip.

Veccio, F.J. 1988. Reinforced Concrete Membrane Element Formulation. Journal of Structural Engineering, . 85(February): 258--268.

Veccio, F.J. 1989. Nonlinear Finite Element Analysis of Reinforced Concrete Membranes. ACI Structural Journals, 86(January - February): 26--35.

Surya, B.U. \& Wibowo, A. 2017. Pengaruh Rasio Tinggi - Lebar $(\mathrm{Hw} / \mathrm{Lw})$ terhadap Kapasitas Beban Lateral Maksimum, Daktilitas dan Pola Retak Dinding Geser Bertulangan Ringan Akibat Beban Siklik. Laporan Hasil Penelitian, Universitas Brawijaya.

Silalahi, J., Wibowo, A., \& Susanti, L. 2016. Pengaruh Variasi Jarak Tulangan Horisontal dan Kekangan terhadap Pola Retak dan Momen Kapasitas Dinding Geser dengan Pembebanan Siklik (Quasi Statis), Tugas Akhir S1 tidak diterbitkan, Universitas Brawijaya. 